\title{
Informal labor and irregular migrant workers
}

\author{
By Masja van Meeteren
}

Link to article: http://dx.doi.org/10.1002/9781444351071.wbeghm302

Irregular migrants, also referred to as "undocumented migrants” or "illegal migrants," are immigrants who do not have legal permission to stay in the country they have migrated to and frequently take on informal and precarious employment. They may have entered the country legally - on a tourist visa for example - but are not allowed to reside or work there. There is broad consensus that the numbers and the global scale of irregular migration have increased over the last decades. Although there are no reliable data, it is estimated that there are between 1.9 and 3.8 million irregular migrants in the EU (Vogel 2009), over 10 million in the US, and over 20 million in India (Koser 2007).

\section{Precariousness of employment}

Irregular migrants are not necessarily informal migrant workers. Although it is often believed that irregular migrants have little choice but to engage in informal employment as a means of survival, not all irregular migrants work. This is because they also have other options to cover their basic needs: they can rely on support from family, friends, or organizations or they can engage in criminal activities. Nevertheless, for irregular migrants employment is an important way to cover basic needs (Engbersen et al. 2006). There are basically three ways in which irregular migrants work. They can engage in informal employment, they can obtain fraudulent working papers, or they can be selfemployed. Because of their weak legal status, many irregular migrants work under difficult conditions for low salaries. Moreover, they can be powerless to do anything about employers' maltreatment as they fear deportation when they report it to the police. Both social scientists and the media tend to focus on sensationalist stories of irregular migrants and their unscrupulous employers (Samers 2001). And indeed, many irregular migrants engage in more exploitative forms of informal employment than other residents do (Williams \& Windebank 1998). However, not all irregular migrants are helpless victims void of agency. Recent European research (Van Meeteren et al. 2009; Van Meeteren 2010) shows that irregular migrants have clear preferences when it comes to work - stemming from more general aspirations they have - and that some irregular migrants manage to get the jobs they desire. Three types of aspirations can be distinguished, each underlying specific work preferences and outcomes. Migrants with investment aspirations aim to earn money in the destination country and to return to their country of origin once they have acquired enough savings. Work is crucial for them, as it allows them to realize their aspirations. They prefer to work as much as possible during their temporary stay, so they try to work six or seven days per week for long hours during those days. These investment migrants work in the sectors that are traditionally associated with irregular migrants: horticulture, construction, personal services, and restaurants. Labor in these sectors usually involves hard work for long hours, which investment migrants are prepared to do temporarily. Investment migrants are also likely to accept the prevailing low wages. These are often below the official minimum, but they are higher than those investment migrants are used to in their countries of origin. From their frame of reference they consequently feel that they are being paid well. Moreover, they value the wages in terms of what they can buy with these in their countries of origin, as their earnings will be spent there.

\section{Migration status and settlement}

Migrants with settlement aspirations aim to start a new life in the destination country and do not intend to return. They prefer steady employment and like to work a regular work week during regular hours, as this allows them to lead a "normal" life. They do not want the jobs investment migrants do because they find these too hard to do for long and too disruptive of their lives. Moreover, typical investment migrant jobs do not pay enough to lead a decent life in the destination country. If they do not manage to find anything else and are obliged to work in sectors where 
mostly investment migrants work, they feel heavily exploited. Migrants with legalization aspirations aim to legalize their status, and working informally could prevent them from reaching this goal. In most countries, if an irregular migrant is caught doing informal work, he or she receives notification to leave the country, which severely reduces the chances of legalization. Therefore, legalization migrants try to work as little as possible. However, if they have no other sources of income, they have to work to sustain themselves, even though they prefer not to engage in informal employment. In these cases they try to find jobs that are not closely controlled by the government, such as domestic work. Because legalization is what these migrants aspire to, they feel exploited if they have to accept informal employment, no matter the type of job. The different aspirations irregular migrants have mean that they display differences when it comes to the amount of hours they want to work, the type of work they like to do, and the exploitation they experience doing it. However, although irregular migrants have specific preferences, not everyone is able to get the job he or she wants. Besides individual aspirations, other factors play a role. Domestic work - preferred by both men and women with settlement or legalization aspirations - is for example traditionally associated with women, which makes it easier for them to access. In addition, while some scholars argue that individual competences such as job qualifications are decisive (GrzymalaKazlowska 2005), others claim that many irregular migrants find jobs through other people, indicating an important role for social capital (Engbersen et al. 2006). Furthermore, the structure of local economies and government policies obviously shape outcomes as well. Some sectors of the economy are, for example, dominated by specific ethnic groups, which makes it easier for irregular migrants of specific ethnicities to find jobs in certain sectors than in others. In addition, some governments have more lenient policies towards the informal employment of irregular migrants than others, which makes it easier to find a job in one country than another (Van Nieuwenhuyze 2009). Irrespective of different claims concerning the underlying causality, most scholars agree that the more informal employment exists in a country, the more irregular migrants are present. However, there are indications that this relationship is becoming weaker in Europe. As labor inspections are becoming more severe, employers increasingly prefer arrangements that have more potency to appear legal than the employment of irregular migrants. Many employers prefer hybrid forms of informal employment, such as fulltime work declared as parttime work, because their workers appear to work legally in case of investigation (Ruhs \& Anderson 2010). Because they cannot work under semiformal arrangements, irregular migrants lose their competitive edge, and are increasingly driven out of the market by those who can. As a result, the employment of irregular migrants increasingly goes "underground" and their working conditions deteriorate (Van der Leun \& Kloosterman 2006).

\section{References and further reading}

Anderson, B. (2001) Doing the Dirty Work? The Global Politics of Domestic Labour. London: Zed Books.

Chavez, L. (1998) Shadowed Lives: Undocumented Immigrants in American Society, 2nd edn. Orlando: Harcourt Brace. (Originally pub. 1992.)

Düvell, F. (ed.) (2006) Illegal Immigration in Europe: Beyond Control? New York: Palgrave Macmillan.

Engbersen, G., Van San, M., \& Leerkes, A. (2006) A room with a view: irregular immigrants in the legal capital of the world. Ethnography 7(2), 209-242.

GrzymalaKazlowska, A. (2005) From ethnic cooperation to ingroup competition: undocumented Polish workers in Brussels. Journal of Ethnic and Migration Studies 31(4), 675-697.

Koser, K. (2007) International Migration: A Very Short Introduction. New York: Oxford University Press.

Mahler, S. J. (1995) American Dreaming: Immigrant Life on the Margins. Princeton: Princeton University Press.

Ruhs, M. \& Anderson, B. (2010) Semicompliance and illegality in migrant labour markets: an analysis of migrants, employers and the state in the UK. Population, Space and Place 16, 195-211. 
Samers, M. (2001) "Here to work”: undocumented immigration in the United States and Europe. SAIS Review 21(1), 131-145.

Schrover, M., Van der Leun, J., Lucassen, L., et al. (eds.) (2008) Illegal Migration and Gender in a Global and Historical Perspective. Amsterdam: Amsterdam University Press.

Van der Leun, J. \& Kloosterman, R. (2006) Going underground: immigration policy changes and shifts in modes of provision of undocumented immigrants in the Netherlands. Tijdschrift voor Economische en Sociale Geografie 97(1), 59-68.

Van Meeteren, M. (2010) Life without papers. Aspirations, incorporation and transnational activities of irregular migrants in the Low Countries. PhD dissertation, Erasmus University, Rotterdam.

Van Meeteren, M., Engbersen, G., \& Van San, M. (2009) Striving for a better position: aspirations and the role of cultural, economic, and social capital for irregular migrants in Belgium. International Migration Review 43(4), 881-907.

Van Nieuwenhuyze, I. (2009) Getting by in Europe’s Urban Labour Markets: Senegambian Migrants' Strategies for Survival, Documentation and Mobility. Amsterdam: Amsterdam University Press.

Vogel, D. (2009) Size and development of irregular migration to the EU. European Commission. At http://clandestino.eliamep.gr/wpcontent/ uploads/2009/12/clandestino_policy_brief_comparative_sizeofirregularmigration.pdf, accessed June 10, 2011.

Williams, C. C. \& Windebank, J. (1998) Informal Employment in the Advanced Economies. Implications for Work and Welfare. London: Routledge. 